\title{
Longitudinal Evaluation of mRNA Vaccinated Subjects using a Quidel Multianalyte Point-of-Care SARS-CoV-2 IgG Immunoassay
}

Authors: Xi Chen ${ }^{1}$, Sarika Agarwal ${ }^{1}$, Stewart Hoelscher ${ }^{1}$, Richard Egan ${ }^{1}$, Dipesh Jaiswal ${ }^{1}$, Adonis Stassinopoulos ${ }^{1}$, Robert Reed ${ }^{1 *}$, Jason McClure', and Werner Kroll ${ }^{1}$

Authors Affiliation:

${ }^{1}$ Quidel Corporation

9975 Summers Ridge Road

San Diego, CA 92121

${ }^{*}$ Corresponding Author:

Robert Reed

Research and Development

9975 Summers Ridge Road

San Diego, CA 92121

Tel\# 858-552-1100; Email: rreed@quidel.com

Conflict of interest statement: The authors have declared that no conflict of interest exists. 
medRxiv preprint doi: https://doi.org/10.1101/2021.05.06.21256544; this version posted May 7, 2021. The copyright holder for this preprint

(which was not certified by peer review) is the author/funder, who has granted medRxiv a license to display the preprint in perpetuity.

All rights reserved. No reuse allowed without permission.

\section{Abstract}

Infection from SARS-CoV-2 elicits an immune response to the nucleocapsid $(\mathrm{N})$ and spike proteins (subunits S1 and S2). In this study, we set out to understand the utility of the multiplexed Quidel Sofia 2 SARS-CoV-2 IgG Antibody Fluorescent Immuno-Assay (FIA) that measures IgG antibodies against these three primary SARS-CoV-2 antigens from a single sample in 15 minutes. Using this assay with samples that were collected prior to the COVID-19 pandemic $(n=816)$ and diseased state samples $(n=99)$, the specificities for the three antigens were $98.4-99.9 \%$ and $98.0-100.0 \%$, respectively. A longitudinal study was designed to collect weekly fingerstick, venous whole blood, serum and plasma samples from subjects vaccinated with the Moderna or Pfizer/BioNtech mRNA vaccines. The majority of these enrolled subjects had no known prior infection while a subset was known to have had prior COVID-19 infection. We found that the fingerstick whole blood samples performed as effectively as serum, plasma, and venous whole blood samples with a 95.8-99.5\% agreement allowing physicians in a nearpatient setting to rapidly provide results to their patients. Additionally, as this assay measures an $\lg \mathrm{G}$ response against three viral proteins, $\mathrm{S} 1, \mathrm{~S} 2$ and $\mathrm{N}$, we were able to characterize immune response between i) naturally infected subjects, ii) vaccinated subjects with no prior infection, iii) vaccinated subjects with known prior infection, and iv) vaccinated subjects with prior asymptomatic exposure/infection. The Quidel Sofia 2 SARS-CoV-2 IgG FIA will aid in providing insights to the protective humoral responses as an increasing number of the world population is vaccinated against SARS-CoV-2. 
medRxiv preprint doi: https://doi.org/10.1101/2021.05.06.21256544; this version posted May 7, 2021. The copyright holder for this preprint

(which was not certified by peer review) is the author/funder, who has granted medRxiv a license to display the preprint in perpetuity.

All rights reserved. No reuse allowed without permission.

\section{Introduction}

As the 2019 Coronavirus (COVID-19) spread rapidly across the world to millions of persons, the administration of a safe and effective vaccine to counter this pandemic became critical. Because of the faster development cycles and the ease of production of mRNA vaccines, efforts focused on developing RNA/molecular-based vaccine delivery systems to target SARSCoV-2. According to $\underline{\mathrm{CDC}}$, by the middle of April 2021, over 190 million Moderna and PfizerBioNTech doses had been administered in the United States. The two vaccines released have similar designs. Both are mRNA vaccines encoding full length modified Spike (S) protein using lipid nanoparticle (LNP)-formulation as a delivery vehicle (1-3). The S protein is a key surface protein on the SARS-CoV-2 surface and the primary target for neutralizing antibodies (4). The injected packaged mRNA/LNP, produces a modified S protein that was shown to be highly immunogenic (5-7). Both vaccines produce cellular as well as humoral immune responses thus inhibiting virus binding to the angiotensin-converting enzyme 2 (ACE-2) receptor $(8,9)$. Published reports show that both vaccines have a protective efficacy of $95 \%$ two weeks after receiving the second dose $(3,10,11)$. As required by the FDA, the mRNA vaccines follow a two-dose regimen, a 2x $100 \mu \mathrm{g}$ dose with Moderna and a 2x $30 \mu \mathrm{g}$ dose with Pfizer-BioNTech $(3,12-14)$.

The Moderna and Pfizer-BioNTech vaccines specifically target the pre-fusion S protein structure by developing modified forms that ensure the $S$ protein does not change its conformation helping to elicit a humoral response to the pre-fusion form of the $S$ protein $(1,2$, $8,15)$. The $S$ protein consists of two subunits: $S 1$ and $S 2$. The receptor binding domain (RBD) region is part of the $\mathrm{S} 1$ subunit. The interaction between RBD and the human ACE-2 receptor is required for viral entry into the host cell. The S2 subunit plays a role in the entry into a host 
medRxiv preprint doi: https://doi.org/10.1101/2021.05.06.21256544; this version posted May 7, 2021. The copyright holder for this preprint (which was not certified by peer review) is the author/funder, who has granted medRxiv a license to display the preprint in perpetuity.

All rights reserved. No reuse allowed without permission.

cell but lacks significant neutralizing epitopes. The nucleocapsid $(\mathrm{N})$ protein is highly immunogenic and is an abundantly expressed protein during infection (16). High levels of lgG antibodies against $\mathrm{N}$ have been detected in sera from COVID-19 patients (16). SARS-CoV-2 serology tests have been developed that target the immune response to different combinations of the S (RBD, S1 and S2 subunits) and N proteins. While most commercial assays target lgG, some also detect $\lg M$ and $\lg A$. Assay types include visually read rapid tests and semiquantitative ELISA assays, and are used with different venous sample matrices (17-20). As more information on the immune response to specific viral proteins becomes available, it may become possible to distinguish between vaccinated and non-vaccinated subjects with and without prior exposure.

With the availability of two mRNA vaccines, each expressing a modified full-length S protein, the focus of a new multiplex serology assay is to independently report the IgG immune response to each of the three, $\mathrm{S} 1, \mathrm{~S} 2$ and $\mathrm{N}$ viral antigens. The primary objective of this study was to better understand vaccination-induced lgG antibody response using Quidel's multiplex lateral flow, Sofia 2 SARS-CoV-2 IgG antibody fluorescent immunoassay (FIA). Further, the assay can distinguish between subjects with prior exposure to the virus pre-vaccination and from subjects without prior exposure pre-vaccination. Additionally, the test identified individuals that had asymptomatic infections or exposures prior to vaccination resulting in a more robust immune responses upon vaccination. As the vaccines do not code for the $\mathrm{N}$ protein, reactivity to the $\mathrm{N}$ protein can only be derived from a COVID-19 infection rather than vaccination. An additional advantage of this assay is the use of a fingerstick sample as opposed to a venous sample as a convenient and effective collection method. 
medRxiv preprint doi: https://doi.org/10.1101/2021.05.06.21256544; this version posted May 7, 2021. The copyright holder for this preprint (which was not certified by peer review) is the author/funder, who has granted medRxiv a license to display the preprint in perpetuity.

\section{Results and Discussion}

The rollout of mRNA vaccines in the US has implications for the interpretation of SARS-CoV-2 serology testing. Prior to the introduction of vaccines, serology tests that detect antibodies specific for major viral proteins would indicate exposure to SARS-CoV-2. After vaccination with the two mRNA vaccines, individuals were routinely monitored for seropositivity against the $S$ protein. This study provides insights into the immune responses elicited from subjects that were vaccinated with either the Moderna or Pfizer-BioNTech vaccine that either had no prior exposure or had prior exposure to SARS-CoV-2.

Reactivity and Specificity of the assay. The Sofia 2 SARS-CoV-2 IgG antibody FIA was evaluated using serum samples from ten RT-PCR confirmed SARS-CoV-2 infected subjects. A longitudinal antibody response against $\mathrm{S} 1, \mathrm{~S} 2$ and $\mathrm{N}$ is shown in Figure 1. Within 8-12 days, a strong IgG response was observed against all three antigens from serum samples from these infected subjects. Specificity of Sofia 2 SARS-CoV-2 IgG antibody FIA was confirmed using 816 COVID-19 negative serum and plasma samples that were collected and stored frozen prior to the COVID-19 pandemic. The observed specificity was determined to be $98.4 \%$ (803/816) for $\mathrm{N}, 99.9 \%$ (815/816) for S1 and $99.0 \%$ (808/816) for S2 (Table 1). In addition, a panel of 99 donors from non-COVID-19 diseased state serum and plasma samples that included subjects characterized with exposure to seasonal coronavirus were also evaluated (Table 1). The specificity of the diseased state samples was $98.0 \%$ (97/99) for N, $100.0 \%$ (99/99) for S1 and $99.0 \%(98 / 99)$ for S2. 

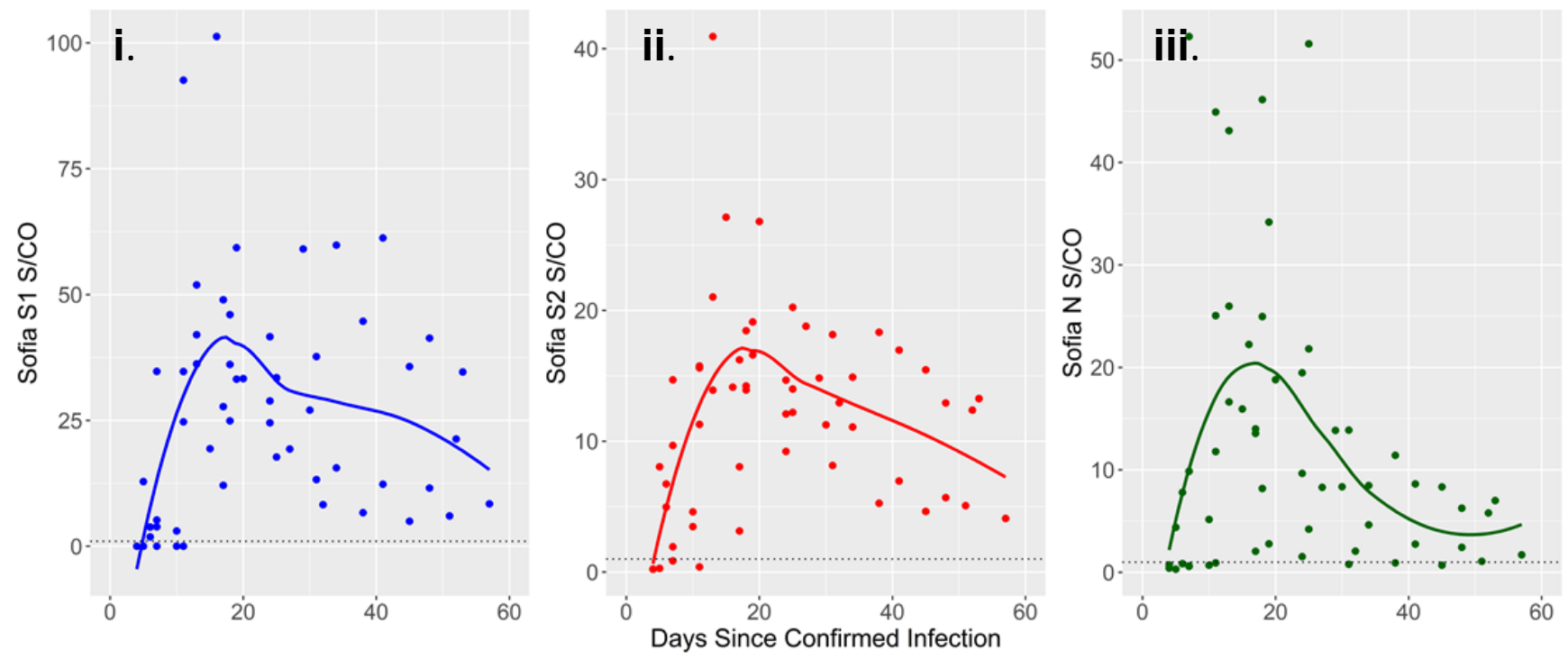

Figure 1. Longitudinal profile of IgG response against SARS-CoV-2 S1, S2 and N antigens from subjects with RT-PCR confirmed COVID-19 diagnosis with no vaccination. Panels i, ii, and iii represent IgG levels against S1 (i), S2 (ii), and N (iii) from banked serum samples from confirmed COVID-19 infected subjects $(n=10)$. IgG response against $S 1$ is represented by a solid blue line, $S 2$ by a solid red line and $\mathrm{N}$ by a green solid line. LOESS fit is used to smooth each line (21). Each blue, red and green dot represents an IgG response against $\mathrm{S} 1, \mathrm{~S} 2$ and $\mathrm{N}$. The $y$-axis represents the S/CO values for $\mathrm{S} 1, \mathrm{~S} 2$ and $\mathrm{N}$. S/CO numbers above 1, marked by the horizontal dashed black line, represent a positive IgG response against $S 1, S 2$ and $N$. Please note the different scales on the $y$-axis. The $\mathrm{x}$-axis represents the time elapsed in days since COVID-19 infection confirmation.

Table 1. Specificity of S1, S2 and N with Pre-COVID-19 Samples and *Disease State Samples.

Samples Antigens Samples Negative Positive Specificity

\begin{tabular}{lccccc}
\hline Pre-COVID 19 Negative & N & 816 & 803 & 13 & $98.4 \%$ \\
Pre-COVID 19 Negative & S1 & 816 & 815 & 1 & $99.9 \%$ \\
Pre-COVID 19 Negative & S2 & 816 & 808 & 8 & $99.0 \%$ \\
& & & & & \\
*Disease State Samples & N & 99 & 97 & 2 & $98.0 \%$ \\
*Disease State Samples & S1 & 99 & 99 & 0 & $100.0 \%$ \\
*Disease State Samples & S2 & 99 & 98 & 1 & $99.0 \%$
\end{tabular}

* Serum/Plasma samples from subjects with known infections other than SARS-CoV-2. 
medRxiv preprint doi: https://doi.org/10.1101/2021.05.06.21256544; this version posted May 7, 2021. The copyright holder for this preprint (which was not certified by peer review) is the author/funder, who has granted medRxiv a license to display the preprint in perpetuity.

All rights reserved. No reuse allowed without permission.

Enrollment and Collection of samples: A multi-center, IRB approved study was designed to collect samples prior to and after the first and second Moderna and Pfizer-BioNTech vaccine doses. Subjects with prior infection, or no known infection prior to the first vaccination were included in this study. Subjects included in the study were male or female, age 18 years or older, and must have had the first blood draw within 7 days of receiving the first COVID-19 mRNA vaccine. Subjects were also required to obtain the second vaccination according to the manufacturer's requirement. Following consent, demographics, symptoms, and health history were collected from each subject (Table 2). Matched fingerstick, venous whole blood, plasma, and serum samples were collected from each subject on a weekly basis. Samples were collected for 3 weeks after the second vaccination dose.

Table 2. Demographics of the study participants.

\begin{tabular}{lccc}
\hline \multicolumn{1}{c}{ Vaccine manufacturer } & Moderna & Pfizer-BioNTech & Total \\
\hline Subjects received 1st and 2nd dose & 52 & 33 & 85 \\
Subjects 3 weeks past 2nd dose & 46 & 29 & 75 \\
Average Days Between Doses & 33 & 21 & NA \\
Gender: & 28 & 14 & 42 \\
$\quad$ Male & 24 & 19 & 43 \\
$\quad$ Female & $19-79$ & $19-83$ & $19-83$ \\
Age Range (Years) & 40 & 40 & 40 \\
Median Age (Years) & 3 & 1 & 4 \\
Subjects with known Prior Infection & 49 & 32 & 81 \\
Subjects with no known Prior Infection & & & 4 \\
\hline
\end{tabular}


medRxiv preprint doi: https://doi.org/10.1101/2021.05.06.21256544; this version posted May 7, 2021. The copyright holder for this preprint (which was not certified by peer review) is the author/funder, who has granted medRxiv a license to display the preprint in perpetuity.

All rights reserved. No reuse allowed without permission.

Of a total of 85 enrolled subjects, 46 subjects that received the Moderna vaccine and 29 subjects that received the Pfizer-BioNTech vaccine were 3 weeks past the second dose. All four samples types from each subject were tested in parallel on the day of collection using the Quidel Sofia 2 SARS-CoV-2 IgG Antibody FIA.

Matrix Comparison: The Sofia 2 SARS-CoV-2 IgG Antibody FIA is designed to be used with fingerstick whole blood, venous whole blood, serum, or plasma samples. In point-of-care settings, the fingerstick whole blood sample is advantageous due to a simple and short collection process that requires a $25 \mu \mathrm{l}$ whole blood sample collected using a disposable plastic capillary tube. In this study we compared the IgG response against $\mathrm{S} 1, \mathrm{~S} 2$ and $\mathrm{N}$ antigens from each of the four sample types over time. Sample matrix equivalency was demonstrated by qualitative percent agreement of the results from fingerstick, plasma, serum, and venous whole blood samples. The qualitative agreement of the fingerstick whole blood results was greater than $95 \%$ with all combinations of sample matrices for all analytes as shown in Table 3. Based on the robust sample equivalency results, the fingerstick sample data was used for analysis of the longitudinal study.

Table 3. Percent agreement between fingerstick whole blood samples and plasma, serum, and venous whole blood samples.

\begin{tabular}{cccc}
\hline \multirow{2}{*}{$\begin{array}{c}\text { Sample Type } \\
\text { Plasma }\end{array}$} & S1 - Fingerstick & S2 - Fingerstick & N - Fingerstick \\
\cline { 2 - 4 } Serum & $98.5 \%(588 / 597)$ & $96.8 \%(578 / 597)$ & $96.3 \%(575 / 597)$ \\
Venous Whole blood & $98.7 \%(586 / 594)$ & $96.1 \%(571 / 594)$ & $95.8 \%(569 / 594)$ \\
& $99.5 \%(594 / 597)$ & $97.0 \%(579 / 597)$ & $97.0 \%(579 / 597)$ \\
\hline
\end{tabular}


medRxiv preprint doi: https://doi.org/10.1101/2021.05.06.21256544; this version posted May 7, 2021. The copyright holder for this preprint (which was not certified by peer review) is the author/funder, who has granted medRxiv a license to display the preprint in perpetuity.

All rights reserved. No reuse allowed without permission.

Longitudinal monitoring of antibody response for vaccinated subjects. The IgG immune response was measured against $\mathrm{S} 1, \mathrm{~S} 2$ and $\mathrm{N}$ from subjects vaccinated with Moderna $(\mathrm{n}=30)$ and Pfizer-BioNTech ( $\mathrm{n}=24)$ but with no known prior exposure to SARS-CoV-2. The primary $\lg \mathrm{G}$ immune response was against the $\mathrm{S} 1$ antigen (Figure $2 \mathrm{~A})$. IgG antibody response was not observed against the $\mathrm{S} 2$ and $\mathrm{N}$ proteins (Figure $2 \mathrm{~B}$ and $\mathrm{C}$ ). We observed that a majority of subjects vaccinated using either mRNA vaccine had an immune response to $\$ 12-3$ weeks after the first vaccine dose. With time points from both vaccine groups normalized to the second vaccine dose, the average antibody response to $S 1$ was similar approximately 2 weeks after the second dose.

In comparison, prior exposure to SARS-CoV-2 should elicit an antibody response against S1, S2 and N proteins. In this study, the immune response for subjects previously exposed to SARS-CoV-2 and vaccinated with Moderna $(n=3)$ and Pfizer-BioNTech $(n=1)$ were higher (Figure 2D) than the $\lg G$ immune response from subjects with no prior exposure to the virus. Following the first vaccination, $\mathrm{S} 1 \mathrm{IgG}$ response of the pre-exposed group was rapid and visibly higher $(\mathrm{S} / \mathrm{CO}>100)$ than the non-exposed subject response $(\mathrm{S} / \mathrm{CO} \sim 15)$. The increased S1 IgG levels in the pre-exposed group was observed 4-5 days after the first vaccination compared to the non-exposed subjects at 13 days. Following the second dose, the pre-exposed subjects $\mathbf{S 1}$ response increased to a similar high response seen after the first vaccination dose (Figure 2D). A previous publication similarly noted a strong reaction to the first COVID-19 vaccine dose in subjects with prior COVID-19 infection. Previously infected subjects in this study had detectable antibodies against S2 and $\mathrm{N}$ antigens as well (Figure 2E and F). 

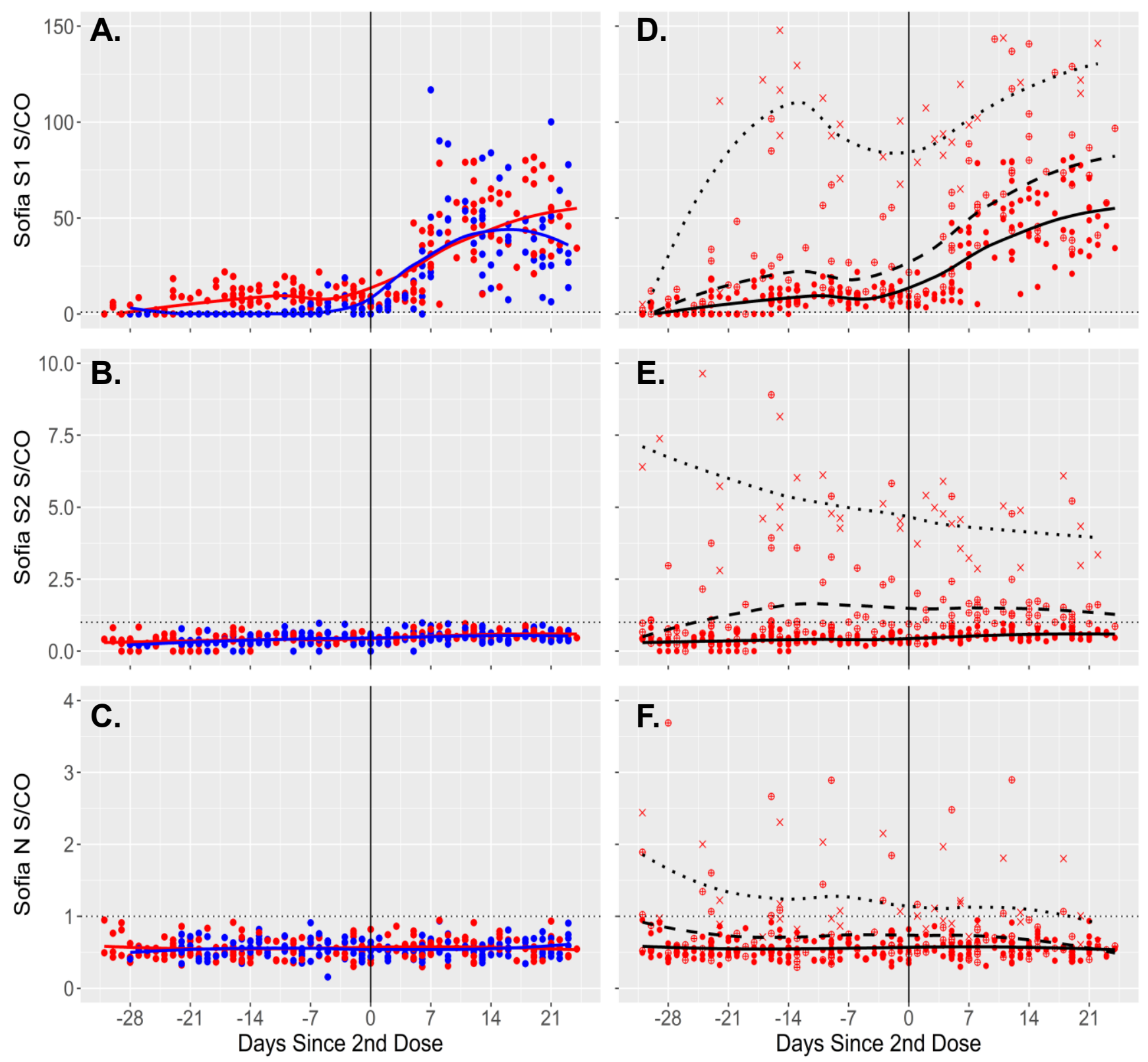

Figure 2. Longitudinal IgG response from fingerstick samples against SARS-CoV-2 S1, S2 and N antigens after vaccination with mRNA vaccines. Panels $A, B$, and $C$ represent lgG levels against $S 1$ (A), S2 (B), and N (C) from subjects immunized with Moderna (Red solid line) and Pfizer-BioNTech (Blue solid line) vaccines with no prior COVID-19 infection. Each red dot represents a Moderna vaccinated sample, and each blue dot represents a Pfizer-BioNTech vaccinated sample. Panels D, E, and $F$ represent IgG levels against S1 (D), S2 (E), and N (F). Samples with no known prior COVID-19 infection are represented by a solid black line, samples with known prior COVID-19 infection are reflected by a bold dotted black line and samples with possible prior exposure to the virus are shown by a dashed black line. A red dot, a red cross and a red circled cross represents a non-infected, a priorinfected and a possible prior exposed sample. LOESS fit is used to smooth each line (21). The solid vertical black line shows the day the second vaccine dose was administered. S/CO numbers above 1, marked by the horizontal dashed black line, represent a positive IgG response against S1, S2 and N. 
medRxiv preprint doi: https://doi.org/10.1101/2021.05.06.21256544; this version posted May 7, 2021. The copyright holder for this preprint (which was not certified by peer review) is the author/funder, who has granted medRxiv a license to display the preprint in perpetuity.

All rights reserved. No reuse allowed without permission.

As the $\mathrm{S} 2$ and $\mathrm{N}$ levels did not increase or spike after the first or the second vaccine dose, they are likely due to prior viral exposure. Vaccines that have received emergency use authorization in the US were designed to elicit an antibody response only against the SARS-CoV-2 S protein and for this reason $\mathrm{N}$ proteins detected in a serological assay are indicative of prior exposure to SARS-CoV-2 regardless of vaccine status $(22,23)$. If only $\mathrm{S} 1$ protein is detected in a serological assay and no $\mathrm{N}$ antibodies are detected, it is consistent with the subject having vaccine-induced antibody response.

A total of 27 subjects, 19 for Moderna and 8 for Pfizer-BioNTech, showed an immune response indicating previous exposure to SARS-CoV-2. These subjects had no prior positive SARS-CoV-2 antigen test, nor had they been symptomatic. After the first vaccination dose, the S1 lgG response in these subjects was increased $(\mathrm{S} / \mathrm{CO} \sim 25)$ as compared to subjects with no prior exposure (S/CO 15). S1 IgG response in subjects with known prior infection were significantly higher $(\mathrm{S} / \mathrm{CO}>100)$. This margin appeared to widen after the second vaccine dose. No IgG response was observed against S2 and N protein. Although, S2 is part of the vaccine S protein construct, S2 appears to have low immunogenicity as has been mentioned previously $(24,25)$. Vaccinated subjects were therefore differentiated into the following categories: no prior infection, known prior infection, and prior asymptomatic exposure/infection.

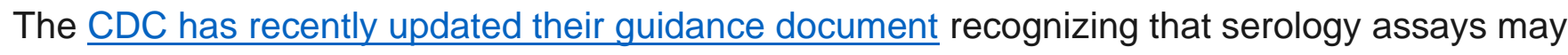
be utilized, "to help differentiate natural infection from vaccination by utilizing tests that measure antibodies against different protein targets." More specifically, a serology test that is IgG positive for either $\mathrm{N}$ or $\mathrm{S}$ with or without vaccination indicates prior infection that could 
medRxiv preprint doi: https://doi.org/10.1101/2021.05.06.21256544; this version posted May 7, 2021. The copyright holder for this preprint (which was not certified by peer review) is the author/funder, who has granted medRxiv a license to display the preprint in perpetuity. All rights reserved. No reuse allowed without permission.

have occurred before or after vaccination. A serology test that is IgG positive for only S1 and negative for other antigens indicates no prior infection with SARS-CoV-2 as all S1 directed antibody resulted from a COVID-19 vaccination.

In this study, we set out to understand the utility of the multiplexed Quidel Sofia 2 SARS-CoV-2 IgG Antibody FIA that measures IgG antibodies against the three primary SARS-CoV-2 antigens $\mathrm{S} 1, \mathrm{~S} 2$ and $\mathrm{N}$ from a single sample in 15 minutes. We conclude that fingerstick whole blood samples performed as well as serum, plasma, and venous whole blood samples. This would provide a distinct advantage to physicians in near-patient settings by providing accurate rapid results for their patients. The Sofia 2 SARS-CoV-2 IgG FIA is intended for use as an aid in identifying individuals with an adaptive immune response to SARS-CoV-2 S1, S2 and N proteins. Additionally, as this assay measures an $\lg G$ response against three viral proteins, $\mathrm{S} 1$, $\mathrm{S} 2$ and $\mathrm{N}$, we can characterize immune response between i) naturally infected subjects, ii) vaccinated subjects with no prior infection, iii) vaccinated subjects with known prior infection, and iv) vaccinated subjects with prior asymptomatic exposure/infection. This study will provide invaluable insights into potential long-term protective humoral response as an increasing number of the world population is vaccinated against SARS-CoV-2. 
medRxiv preprint doi: https://doi.org/10.1101/2021.05.06.21256544; this version posted May 7, 2021. The copyright holder for this preprint

(which was not certified by peer review) is the author/funder, who has granted medRxiv a license to display the preprint in perpetuity.

All rights reserved. No reuse allowed without permission.

\section{Methods}

Sofia 2 SARS-CoV-2 IgG Antibody FIA assay. The Sofia 2 SARS-CoV-2 IgG Antibody FIA is a single-use lateral flow rapid assay for the semi-quantitative detection of $\lg G$ antibodies to SARS-CoV-2 S1, S2 and N proteins. Sample types tested included fingerstick and venous whole blood, plasma, and serum derived from subjects prior to vaccination and at multiple time points after the first and second vaccinations. This assay utilizes three recombinant SARSCoV-2 proteins that are separately immobilized on the lateral flow test strip. The recombinant N, S1 and S2 proteins consist of 425 amino acids, 681 amino acids and 539 amino acids, respectively. To perform the test with fingerstick and venous whole blood, a $25 \mu \mathrm{L}$ sample was collected into a disposable capillary device. This whole blood sample was diluted 40 -fold and $100 \mu \mathrm{l}$ of this diluted sample was applied to the sample port of the test cassette containing the three immobilized antigens. For serum and plasma samples, $10 \mu \mathrm{L}$ of the sample was diluted 100 -fold and $100 \mu \mathrm{L}$ was applied to the sample port of the test cassette. The SARS-CoV-2 IgG antibodies present in the sample, bind to fluorescent beads containing anti-human IgG antibodies and subsequently bind to the immobilized S1, S2 and $\mathrm{N}$ antigens. The test cassette was placed in the Sofia 2 instrument and the $\lg$ G levels for each antigen were obtained at 15 minutes. The positive or negative values for each antigen are based on signal to cutoff ratios $(\mathrm{S} / \mathrm{CO})$ where $\mathrm{S} / \mathrm{CO} \geq 1$ is positive and $\mathrm{S} / \mathrm{CO}<1$ is considered negative.

Statistical analysis. Data was normalized to the second vaccination day (Figure 2). LOESS smoothing with a span of 0.75 and degree of 2 was used to fit the longitudinal data of subjects within a category (21). R version 4.03 and RStudio version 1.4 .1106 were used for study data analysis. Figures were generated using package ggplot2, version 3.3.3. 
medRxiv preprint doi: https://doi.org/10.1101/2021.05.06.21256544; this version posted May 7, 2021. The copyright holder for this preprint (which was not certified by peer review) is the author/funder, who has granted medRxiv a license to display the preprint in perpetuity. All rights reserved. No reuse allowed without permission.

Acknowledgements: This study was funded by Quidel Corporation. We thank the contributions of the following Quidel employees: Adriana Gamboa, Nerliza Jimenez, Andrew Westberg, Bridget Balzon, Gabrielle Cruz, Allen Lalaian, Kenny Hwang, Lisa Pysz, Arianna Paik, Veronica Aziz, Kelly Brooks, Aaron Weston, Amanda Li, Cristina Charles, Minnie Chan, and Alexander Liu.

QUIDEL and SOFIA are registered trademarks of Quidel Corp. All other trademarks belong to their respective owners and their use herein does not imply sponsorship or endorsement of their products or services. 
medRxiv preprint doi: https://doi.org/10.1101/2021.05.06.21256544; this version posted May 7, 2021. The copyright holder for this preprint (which was not certified by peer review) is the author/funder, who has granted medRxiv a license to display the preprint in perpetuity.

\section{References}

1. Walsh EE, Frenck RW, Jr., Falsey AR, Kitchin N, Absalon J, Gurtman A, et al. Safety and Immunogenicity of Two RNA-Based Covid-19 Vaccine Candidates. N Engl J Med. 2020;383(25):2439-50.

2. Jackson LA, Anderson EJ, Rouphael NG, Roberts PC, Makhene M, Coler RN, et al. An mRNA Vaccine against SARS-CoV-2 - Preliminary Report. N Engl J Med. 2020;383(20):1920-31 .

3. Polack FP, Thomas SJ, Kitchin N, Absalon J, Gurtman A, Lockhart S, et al. Safety and Efficacy of the BNT162b2 mRNA Covid-19 Vaccine. N Engl J Med. 2020;383(27):260315.

4. Leung DT, Tam FC, Ma CH, Chan PK, Cheung JL, Niu H, et al. Antibody response of patients with severe acute respiratory syndrome (SARS) targets the viral nucleocapsid. J Infect Dis. 2004;190(2):379-86.

5. Wang F, Kream RM, and Stefano GB. An Evidence Based Perspective on mRNASARS-CoV-2 Vaccine Development. Med Sci Monit. 2020;26:e924700.

6. Corbett KS, Edwards D, Leist SR, Abiona OM, Boyoglu-Barnum S, Gillespie RA, et al. SARS-CoV-2 mRNA Vaccine Development Enabled by Prototype Pathogen Preparedness. bioRxiv. 2020.

7. Sharma O, Sultan AA, Ding $H$, and Triggle CR. A Review of the Progress and Challenges of Developing a Vaccine for COVID-19. Front Immunol. 2020;11:585354.

8. Widge AT, Rouphael NG, Jackson LA, Anderson EJ, Roberts PC, Makhene M, et al. Durability of Responses after SARS-CoV-2 mRNA-1273 Vaccination. N Engl J Med. $2021 ; 384(1): 80-2$. 
medRxiv preprint doi: https://doi.org/10.1101/2021.05.06.21256544; this version posted May 7, 2021. The copyright holder for this preprint (which was not certified by peer review) is the author/funder, who has granted medRxiv a license to display the preprint in perpetuity. All rights reserved. No reuse allowed without permission.

9. Sewell HF, Agius RM, Kendrick D, and Stewart M. Covid-19 vaccines: delivering protective immunity. BMJ. 2020;371:m4838.

10. Baden LR, El Sahly HM, Essink B, Kotloff K, Frey S, Novak R, et al. Efficacy and Safety of the mRNA-1273 SARS-CoV-2 Vaccine. N Engl J Med. 2021;384(5):403-16.

11. Anderson EJ, Rouphael NG, Widge AT, Jackson LA, Roberts PC, Makhene M, et al. Safety and Immunogenicity of SARS-CoV-2 mRNA-1273 Vaccine in Older Adults. $N$ Engl J Med. 2020;383(25):2427-38.

12. Klasse PJ, Nixon DF, and Moore JP. Immunogenicity of clinically relevant SARS-CoV-2 vaccines in nonhuman primates and humans. Sci Adv. 2021;7(12).

13. Oliver SE, Gargano JW, Marin M, Wallace M, Curran KG, Chamberland M, et al. The Advisory Committee on Immunization Practices' Interim Recommendation for Use of Moderna COVID-19 Vaccine - United States, December 2020. MMWR Morb Mortal Wkly Rep. 2021;69(5152):1653-6.

14. Oliver SE, Gargano JW, Marin M, Wallace M, Curran KG, Chamberland M, et al. The Advisory Committee on Immunization Practices' Interim Recommendation for Use of Pfizer-BioNTech COVID-19 Vaccine - United States, December 2020. MMWR Morb Mortal Wkly Rep. 2020;69(50):1922-4.

15. Walsh EE, Frenck R, Falsey AR, Kitchin N, Absalon J, Gurtman A, et al. RNA-Based COVID-19 Vaccine BNT162b2 Selected for a Pivotal Efficacy Study. medRxiv. 2020.

16. Cong $\mathrm{Y}$, Ulasli M, Schepers H, Mauthe M, V'Kovski P, Kriegenburg F, et al.

Nucleocapsid Protein Recruitment to Replication-Transcription Complexes Plays a Crucial Role in Coronaviral Life Cycle. J Virol. 2020;94(4). 
medRxiv preprint doi: https://doi.org/10.1101/2021.05.06.21256544; this version posted May 7, 2021. The copyright holder for this preprint (which was not certified by peer review) is the author/funder, who has granted medRxiv a license to display the preprint in perpetuity. All rights reserved. No reuse allowed without permission.

17. Whitman JD, Hiatt J, Mowery CT, Shy BR, Yu R, Yamamoto TN, et al. Evaluation of SARS-CoV-2 serology assays reveals a range of test performance. Nat Biotechnol. 2020;38(10):1174-83.

18. GeurtsvanKessel $\mathrm{CH}$, Okba NMA, Igloi Z, Bogers S, Embregts CWE, Laksono BM, et al. An evaluation of COVID-19 serological assays informs future diagnostics and exposure assessment. Nat Commun. 2020;11(1):3436.

19. Oved K, Olmer L, Shemer-Avni Y, Wolf T, Supino-Rosin L, Prajgrod G, et al. Multicenter nationwide comparison of seven serology assays reveals a SARS-CoV-2 nonresponding seronegative subpopulation. EClinicalMedicine. 2020;29:100651.

20. Schuler CFt, Gherasim C, O'Shea K, Manthei DM, Chen J, Giacherio D, et al. Accurate point-of-care serology tests for COVID-19. PLoS One. 2021;16(3):e0248729.

21. Chambers JM, and Hastie T. Statistical Models in S. Wadsworth \& Brooks/Cole Advanced Books \& Software; 1992.

22. Burbelo PD, Riedo FX, Morishima C, Rawlings S, Smith D, Das S, et al. Detection of Nucleocapsid Antibody to SARS-CoV-2 is More Sensitive than Antibody to Spike Protein in COVID-19 Patients. medRxiv. 2020.

23. Burbelo PD, Riedo FX, Morishima C, Rawlings S, Smith D, Das S, et al. Sensitivity in Detection of Antibodies to Nucleocapsid and Spike Proteins of Severe Acute Respiratory Syndrome Coronavirus 2 in Patients With Coronavirus Disease 2019. J Infect Dis. 2020;222(2):206-13.

24. Ravichandran S, Coyle EM, Klenow L, Tang J, Grubbs G, Liu S, et al. Antibody signature induced by SARS-CoV-2 spike protein immunogens in rabbits. Sci Trans/ Med. 2020;12(550). 
medRxiv preprint doi: https://doi.org/10.1101/2021.05.06.21256544; this version posted May 7, 2021. The copyright holder for this preprint (which was not certified by peer review) is the author/funder, who has granted medRxiv a license to display the preprint in perpetuity.

All rights reserved. No reuse allowed without permission.

25. Bos R, Rutten L, van der Lubbe JEM, Bakkers MJG, Hardenberg G, Wegmann F, et al. Ad26 vector-based COVID-19 vaccine encoding a prefusion-stabilized SARS-CoV-2 Spike immunogen induces potent humoral and cellular immune responses. NPJ Vaccines. 2020;5:91. 